\title{
On College Students' Entrepreneurship Education
}

\author{
Xiao Wang \\ School of Foreign Languages \\ Huanghe Science and Technology College \\ Zhengzhou, China
}

\begin{abstract}
College students' entrepreneurship education is an important approach to realizing the function of higher education under the circumstances of educational situation in our country. Solution of college students' employment is an important topic of the current higher education. Therefore, through the development of college entrepreneurship education, colleges can explore new education mode, and improve university students' entrepreneurship and employment competitiveness. It also plays a positive role in solving the problem of college students' employment. This thesis mainly talks about the present situation of college students' entrepreneurship in China, and several factors preliminarily affecting it. Then it discusses how to build the business-pioneering education target system, so as to promote the development of entrepreneurship education in our country more effectively.
\end{abstract}

Keywords—entrepreneurship education; target system; status

\section{INTRODUCTION}

In 1972, the UNESCO ,in the report "Learn to Survive", puts forward entrepreneurship quality should be basic quality of citizens. The UNESCO held " The International Development Trend of Education in the Coming 21st Century" Seminar in Beijing in 1989, during which it formally put forward the concept of "entrepreneurial education". From a broad sense, it is very important to carry out the entrepreneurship education which is greatly effective to cultivate pioneering individuals, personal initiative and adventurous spirit, and the ability to work independently as well as the technical, social, management skills. College is instructed to combine entrepreneurial skills and entrepreneurial spirit as the basic goal of higher education. Academic research and professional education are equally important in position. In 1995 the UNSECO provide a complete concept of entrepreneurship education which includes two aspects: job-hunting and to create new jobs. At the world conference in 1998 on Higher Education Session, it further stressed: higher education should develop entrepreneurial skills and initiative, and graduates should not only become job seekers but the creator of jobs. In the last century, the famous educator Tao xingzhi mentioned that "The aim of life is to create new job opportunities". Mr. Tao's point of view is very worthy of pondering for contemporary college students. While in 1989, the UNESCO puts forward the concept of "entrepreneurial education", and points out that "entrepreneurship" is the third passport [1], But after that, the Chinese society did not have too much attention on it. In recent years, with the development of market economy and globalization trend, "college student's entrepreneurship" is becoming the hot topic of society.

\section{The PRESENT Situation OF OUR College STUDENTS' ENTREPRENEURSHIP AND THE EXISTING PROBLEMS}

In recent years, in order to support entrepreneurship for college students, all levels of government issued many preferential policies, which involving many aspects, such as finance, taxation, business training, etc. Chinese government stressed to implement the development strategy of expanding employment, promoting and encouraging entrepreneurship to create more employment opportunities. Government should support young people's self-employment, seek a profession oneself, and strengthen the employment concept of education, make more workers to become entrepreneurs [2]. Now, there is a great breakthrough for the college students' entrepreneurship in our country.

Though the government provides relatively loose environment for the college students' entrepreneurship, but the current situation is still not optimistic. There are still many obstacles.

\section{A. Bottleneck 1: Lack of Market Consciousness}

The core part of the college students' entrepreneurship support is technology. When looking for investors ,they often emphasizes that how leading the technology is, but they cannot put forward the feasible marketing plan in accordance with their products, and no market is equal to zero.

\section{B. Bottleneck 2: Business Management Experience}

As the freshman in the market, they have more theories than real practice. They have no theory of adequate experience, which is difficult to operate according to the market environment.

\section{Bottleneck 3: Low Levels of Science Or Technology, and No Subsequent Products}

Accounted for most of the college students' entrepreneurial failure, one important reason is that they normally ignore the technical innovation, although they can earn money in the beginning but no longitudinal expansion 
technology products to adapt to the market, which makes their founded enterprises only have 2 or 3 years of life.

\section{Bottleneck 4:Lack of Start-up Capital.}

College students' self-employment is often short of money, in addition to some families can provide money for their children, the vast majority of college students pin their hope on venture capital. They hope to attract investors with a novel idea, however, investors care more about science and technology content, market share, and many other aspects, which makes it really difficult to get investment.

\section{THE CURRENT FACTORS WHICH HAVE INFLUENCE ON ENTREPRENEURSHIP EDUCATION.}

From the Angle of higher education, at present, the factors that affect entrepreneurship education are the following several aspects.

\section{A. Out-of-date Education Ideas}

Education ideology is the objective reality and the requirement of the whole society and education in the awareness of educators. It plays an orientational role in education and guidance. In the various factors which restrict the development of the higher education reform, the first one is the backwardness of education thought. Due to the profound historical, social and cultural reasons, especially the imperial examination system, scorn, suppression, ranking of the feudal thought and the influence of planned economy, it is really difficult to get a fundamental shift and breakthrough. Such as the quality of students only depends on the scores, talent ability is only depending on their educational degree. It seeks pure teaching knowledge from books, and sets the single curriculum of subjects. The educator has general requirements, and neglect personality development[3]. They pay attention to the evaluation of the examination results, and assesses the morality of students' ideological and political performance according to the student' attendance rate and so on.

These backward ideas seriously restrict the deepening of education reform. It bind personal and psychological quality and also blocks the development of creative thinking. So after graduation, it is difficult to adapt to the needs of economic development and social progress.

\section{B. Lack of Education Funds Investment}

Lack of financial education funds ,in the most direct, realistic and concentrated realization is that the colleges, in order to guarantee the necessary basic conditions for construction, raise money to make up the financing gap, to implement entrepreneurship education platform, and even hardware construction projects, carrier and so on .But in the real practice, not only financial input and self-raised funds for entrepreneurship education in colleges and universities support is very limited, but also social investment for returns have long cycles and uncertainty[4].

\section{The Education System Has Disadvantages}

On the one hand, either by the traditional college education in our country, and the influence of the Soviet Union, the education system, there are many disadvantages for entrepreneurship education a substantial promotion and improvement. Specifically, there are three main drawbacks: one is the teaching content tend to pragmatic professional, which inhibits the comprehensive development of quality. Quick success is the most typical negative effect of market economy in higher education. The second is the formalism of teaching organization, which suppresses the freedom to explore space. Meanwhile, classes dividing system blocks students' individual personality. The third one is that teach toward dogmatic teaching type, which affected the formation of innovative thinking.

Force-feeding teaching methods, teacher is the absolute leading role. They dominate classroom, script the textbook. So it has become a common phenomenon and no equal dialogue in the academic atmosphere. The dignity of teacher blocked the exchange and communication with students.

\section{Negative Impacts of Exam-oriented Education}

The disadvantages of exam-oriented education is obvious and has always been criticized by the parties, but at all stages of primary, secondary and university, they still can't get away from the shackles of " Score is the highest ". Under the condition of exam-oriented education, from the point of educators, due to the assessment standards of teachers is the students' graduation rate, teachers have to pass on to students, to evaluate the students quality according to their academic performance. They put emphasis on book knowledge in the teaching, but neglecting the students' quality and ability. From the point of educators, to cope with all kinds of test distinction, don't have enough time and energy to exercise ability of applying knowledge to solve practical problems[5]. Let alone to pay attention to apply the knowledge to innovation, creativity and entrepreneurship, and strengthen the psychological quality cultivation. Under the examoriented education background, the deviation from the teaching and learning appeared. The comprehensive quality become insignificant, entrepreneurship-needing intelligence and personality characteristics are difficult to develop.

\section{PATH SELECTION OF STUDENTS' ENTREPRENEURSHIP EDUCATION}

\section{A. Build Entrepreneurship Education Curriculum System}

Entrepreneurship education should also depend on teaching to play the role of the main channel of the classroom teaching. They should put the entrepreneurship education courses on the talent training scheme according to the target system. First, in the form of a required or elective courses, courses such as entrepreneurship, creative study, scientific and technological inventions, leadership science, management should be set up to cultivate the pioneering consciousness, experience and knowledge. Second, in the teaching of subjects, by means of penetration, combination and strengthening, the college students' entrepreneurship education into deeply. Entrepreneurship need all levels of 
knowledge, therefore a variety of courses should widely infiltrate in the entrepreneurship education. This way doesn't need to break the existing curriculum system, but need to enhance the content of entrepreneurship education.

\section{B. Strengthen College Students' Entrepreneurial Practice}

Entrepreneurial activity has a strong social practice, entrepreneurship education in the cultivation of the ability should act as the core operation. Strengthen the entrepreneurial practice has the following three models: one is the "Base + Students", which including campus and outside ones. The campus base including school-run enterprises, scientific research park, business center, business community, work-study center. While the outside base refers to the factories, rural areas, enterprises, schools, etc.

The second is "project + students". Colleges and universities should put up enough money, set up small, practical, and frontier science research projects, for students to declare a competitive project and to cultivate innovative thinking in the scientific research activities. Entrepreneurship competition activities in China began in 1998, Tsinghai university, the college students' entrepreneurship design competition held in 1999. It is the first one to start the "Challenge Cup" for Chinese college students business plan competition, and so far become the most influential national competitions. Entrepreneurship competition is an effective way to implement entrepreneurship education, and is very beneficial to college students' self-employed after graduation.

\section{Create a Good Atmosphere of Entrepreneurship Support}

Affected by planned economy under the conditions of the influence of the "turn-key" unification, quite a number of college students lack of confidence or they don't want to be self-employed. Build support and encourage entrepreneurship and good campus atmosphere is crucial on how to make college students in thinking and understanding, from "work for me" to "I'm looking for a job", and finally to "I work to create" . First, on the propaganda public opinion, colleges should use radio, newspaper, campus newspaper, $\mathrm{TV}$, Internet and other tools for business promotion, the height of the share for the society, and make contributions to society. They should set up the "entrepreneurs is the hero of contemporary society, is the elite of ethnic groups"[6] .With these new ideas, they can make business success the career standard of college students. Second, on the business environment, to ensure free and easy, work out policies to support and encourage entrepreneurship, such as the business to provide the necessary funds, information, field support and technical consultation instruction, implement credit system, business suspension, such as being flexible. Third, in a typical education, take the way of "going out, please come in", let students understand and comprehend the successful history. Meanwhile, special attention should be paid to play the model demonstration effect of distinguished alumni, for example, the college can often invite them back to his Alma mater to make up report, deliver the speech, and join the face-to-face dialogue with fellow students. Create entrepreneurship education teachers' team, To implement entrepreneurship education, we must have excellent education resources and teachers as the guarantee. Teachers' leading role is critical in entrepreneurship education. How to fast and well establish it? The most effective way is to increase the training and pay attention to the elite introduction. First, through courses in entrepreneurship education to develop the elite."Hiring is one of the best training". The college should choose them who have the good foundation bear the entrepreneurship education curriculum, make them grow up as soon as possible in theory and real practice. Second, send teachers to well-known enterprises to visit, study and get training. In the innovation development of the enterprise ,they can accumulate business experience and master rich material of entrepreneurship education and typical cases. Third, entrepreneurial success can be invited to become a part-time teacher, lectures (guest).They can regularly or irregularly give lectures on campus, and combine theory with practice. For college students, it is a good form of entrepreneurship education, at the same time can also drive the progress and development of teachers, which provide safeguard for the implementation of entrepreneurship education.

\section{REFERENCES}

[1] Higher Education in Europe. http://ec.europa.eu/education/lifelonglearning-policy/doc62_en.htm. 2008.

[2] Plaschka,G.R.,Welsch,H.P.Emerging Structures in Entreprenurship Education:Curricular Designs and Strategies. Entreprenurship Theory and Practice. 1990.

[3] The National Council for Graduate Entrepreneurship.Enterprise and Entrepreneurship in Higher Education:A Report of the 2010 Study by NCGE and ISBE http://www.ncee.org.uk/publication/enterprise_and_entrepreneurship _in_higher_education_full.pdf. 2010.

[4] MIT Entrepreneurship Center Annual Repor[tZ] http://entrepreneurship.mit.edu/Downloads/ar_complete.pdf. 2002.

[5] Roberts,E.B.,Eesley,C.Entrepreneurial Impact: The role of MIT. http://www.kauffman.org/uploadedFiles/MIT_impact_full_report.pdf. 2009.

[6] Oklahoma State University.OSU University-wide Entrepreneurship Initiatives. http://entrepreneurship.okstate.edu/cw/initiatives/. 2011. 